\title{
砂層の圧力分布飞関する一実験
}

正員後藤正司*

\section{AN EXPERIMENT OF PRESSURE DISTRIBUTION IN SAND-LAYER}

\author{
Shoji Goto, C. E. Member
}

Synopsis; With a view to measuring pressure distribution in comparatively thin sand-layer, the power required and the sand-layer displacement occurring when pulling up a plate buried in sand-layer were simulteneously recorded.

The results of the experiment show an example of determining pressure distribution in sand-layer and the critical angle of normal pressure on it.

要旨 比較的薄い砂層内の圧力分布を測定する目的を以て砂層内に大れを小血を引上げる眭の力と変位を同時記 録した。この結果から砂層内の圧力と垂值圧力の限界角を推定せんとする一例を述べするのである。

\section{(1) 緒 言 \\ （2） 実験方法及記錄解析法 \\ (3) 引上抵抗による測定結果}

目次

(4) 限界角に就て

（5）載荷せる場合の圧力

(6) 結 言

\section{1. 緒 需}

土中の圧分布に就ては土圧理論の発展と共にその害験測定も之委で色々と行はれて来てるる。然し乍ら圧力 測定といふものが本来必らず変位学伴つて測定されるものであるから，比較的弾性率の大きい物質に於いてはそ の歪が測定出来る場合は無難であららが，変位の大きいものにとつては変位をなす前後の状態が，かなり異るた めに厳密な意味厄゙ある一定の状態の圧力赏求めるといふことが困難となる。又測定器が面究持ち，その面が受け る力を測定する仕組のもので注測定器の面と材料との接触が思ふようにならない。喧をしく言へば測定器自身の 面の変形が問題になつてくるのである。これは材糊の粗密に依つて異るのであるが水圧や気圧の測定に於てい考 ヘられない事であ万弓。以上の团難さ学除き得る応力測定器が出現してるない今日, 土砂中の圧力を正確比知る

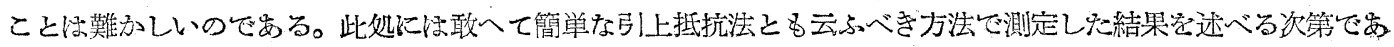
る。只以上の困難の一つの点を避ける守めに，カと変位の同時記録をしたのである。

\section{2. 実験方法及記錄解析法}

図一1 に示す如く大いサ $(40.9 \mathrm{~cm} \times 32.7 \mathrm{~cm} \times 9.5 \mathrm{~cm})$ の木箱に乾懆砂を大れ小板をこの砂の中に埋めこれを スプリングで引上げる仕組である。砂は現場等で通常使用されるものを用ひたが，その組成隹次表の如くであつ to

\begin{tabular}{|c|c|c|c|c|c|c|c|c|c|}
\hline 符 & 番 & 묵 & 30 & 40 & 50 & 60 & 220 & 250 & \\
\hline 㨁 & & 径 & .503 & .361 & .279 & .221 & .061 & & $(\mathrm{~mm})$ \\
\hline 重 & 量 & 比 & 8.0 & 22.4 & 26.0 & 16.0 & 27.0 & 0.6 & $(\%)$ \\
\hline
\end{tabular}

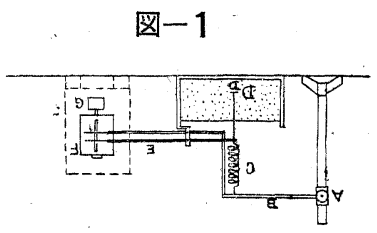

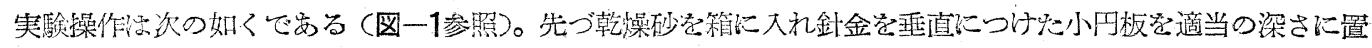
き軽く砂にて埋め砂表面学平にならしな後針金究スプッングの自然長さに於いて吊す。このスプリングと，引上 量学示与べき鈳杆と急腕木 $\mathrm{B}$ に取付けこれ学スクリューA を迴転して静かに上げる。此の引上量と砂中の小 円板の移動量恬平行光線に依りオッシロ用のドラムの问画紙比記録される。ドラムの回転は略1分間に 1 回転の

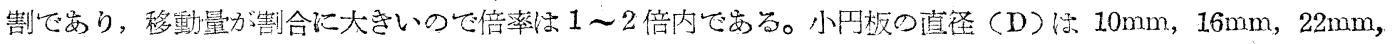
$20 \mathrm{~mm}$ と 4 種のもの叒用ひた。針金と砂との摩擦力は砂層厚 $4 \mathrm{~cm}$ に対して $2 \mathrm{~g}, 9 \mathrm{~cm}$ に対して $7 \mathrm{~g}$ 程度であっ

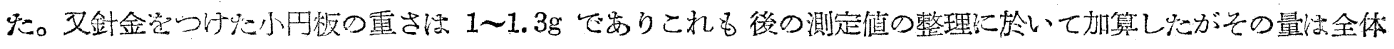
の值に対して極めて小量厄゙る。引上力として利用したスプリングに就いては各ふ伸びと力の曲線离求め後にこ 
のグラフから引倠力在推定しけ。

記録解析法

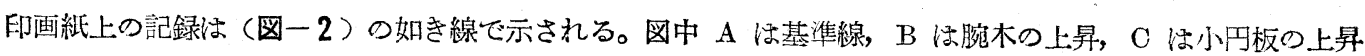
を示してぬる。

斯の如き記録に就いて引上土玨次の如く 3 種に分けて考へる。

（1）始動土圧 スタートよりこの時をでの直線的な移動は局部的に小円板の 附近で砂の空吵が小さくなる為に生ずるものと考へ，この点から比較的全体に影

響兴持つ砂の移動が始まるものと考へ岕。図に於ては S 点の如き点の土圧。

図-2

（2）流動土圧 砂粒子が運動を起して後，をさに粒子間の亡り觉始めんとする時の土圧。記録写真を見てか くの如き変化を起していると考へられる点の中で最大值を求める。(図一2)に於て $\mathrm{S}^{\prime}-\mathrm{F}$ 間の土圧の最大值。

（3）破壊土圧 砂の組織が上の如き氙を始めてから，引上力の增加なしに変位を増し始める封の土圧（図 -2) K於てD点の土圧。

以上 3 点について引上抵抗を求めるのであるが，小円板の上舁に從ひその前後の引上力は違つてるるわけであ る。そこでスプッングの弾性係数を考慮し引上力の変化を淔線的なるものと仮定し上昇前後の值の平均を取つた。 例へば（図一2）に於いて始動土圧 $\mathrm{S}$ に就ては $1 / 2\left\{L_{s}+\left(L_{s}-l_{s}\right)\right\}$, 流動土圧 Fに対しては $1 / 2\left\{L_{F}+\left(L_{F}-l_{F}\right)\right\}$, Dに対しては $1 / 2\left\{L_{D}+\left(L_{D}-l D\right)\right\}$ なる各々の伸びに就てスフリングの力を求めたのである。

\section{3. 引上抵抗に依る測定結果}

砂層全体の厚さは常に $9.5 \mathrm{~cm}$ に保台小円板の深さを変 へて測定した。その結果砂層深さと垂直圧力の関係は図一 3 の如くである。3つの場合の圧力は殆ど同様な傾向であ るが，何れも $7 \mathrm{~cm}$ の梁さに於ける值が急に大きく出てる るのは，箱の両側からきてるる Arch action であるとも思 はれる。

又，小円板の直径に就て見ると值径の小なるうが゙大きな

図-3

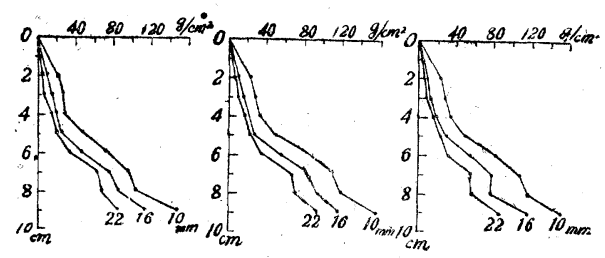

圧力を示してるることがわかる。これは，面に受ける圧力を測定するやうな方式の測定器に依る場合に考ふべ 点だと思はれる。測定記録の写真上り応力と変位の関係を求めて見ても(図省略) 小円板の直径による違ひは明 かに現はれてくる。又，買の深い時程流動的変位が大きくなる上5である。

\section{4. 限界角に就て}

前述の如く小円板の大いさが引上抵抗に違つ値を与へるといふ事から，砂の 移動の限界を求めることが出来るのではないかと考へた。先づ小円板の上に頂部 のない逆立円錐形を考へこの部分の重量と，円錐形の側面に於ける摩擦力の垂值 分力との和を引上抵抗とし, 円錐形の側面の傾斜角 $\varphi$ を各深さに対して求めよ

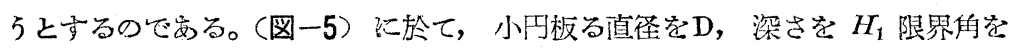
ゅとすれば截頭円錐 $\mathrm{A}, \mathrm{B}, \mathrm{C}, \mathrm{D}$ の体積 $V_{1}$ は

$$
\dot{V}_{1}=\frac{12}{\pi}(D+2 h \tan \phi)^{2}\left(h+\frac{D}{2} \frac{1}{\tan \phi}\right)-\frac{1}{24} \frac{\pi D^{3}}{\tan \phi}
$$

これより円筒 $\mathrm{A}, \mathrm{B}, \mathrm{E}, \mathrm{F}$ を除いと部分の体積 $V$ は

$$
V=V_{1}-\frac{\pi D^{2}}{4}=\frac{\pi}{12}\left(6 h^{2} D \tan \phi+4 h^{3} \tan ^{2} \phi\right)
$$

となる。双て砂の単位体積の重量を $w$ ，内部摩擦角を $\rho$ とすると $d \theta$ 間の体積 の重量 $W$ は

$$
W=\frac{V}{2 \pi} d \theta \cdot w
$$

この $d \theta$ 陪分の側面に作用する摩擦力 $f$ は

$$
f=\tan \rho \cdot W \sin \phi=\tan \rho \frac{V}{2 \pi} w \cdot \sin \phi \bullet d \theta
$$

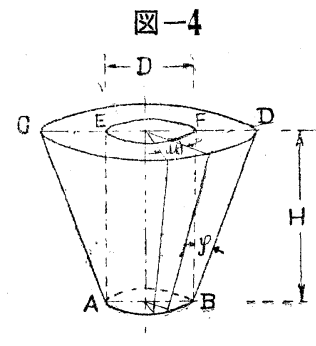

図-5

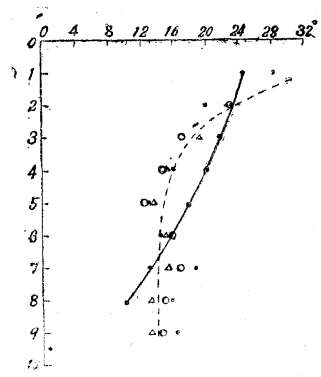

全側面の摩擦力 $F^{\prime}$ 注

$$
F^{\prime}=\int_{0}^{2 \pi} \frac{V w}{2 \pi} \tan \rho \sin \varphi \cdot d \theta=V \cdot w \sin \varphi \text { ton } \rho
$$


この垂直分力 $F$

$$
F=V \cdot u \sin \varphi \tan \rho \cos \varphi
$$

注故に実験値 $P_{0}$ (引上抵抗) は砂の重量とこの摩擦力の垂值分力との和として

$$
P_{0}=V_{1} \cdot w+V \cdot w \sin \varphi \operatorname{sos} \phi \tan \rho
$$

の如く示される。

小円板上の円筒部分の重量を除けばその時の引上カ $P$ としては

$$
\begin{aligned}
P & =V \cdot w+V_{i w} w \sin \varphi \cos \varphi \tan \rho \\
& =\frac{\pi}{12} w\left(6 h^{2} D \tan \varphi+4 h^{3} \tan ^{2} \phi\right)\left(1+\frac{1}{2} \sin 2 \phi \tan \rho\right)
\end{aligned}
$$

今砂の凝集力を無視し，安息角 $\rho$ を以て内部摩擦角と見做して $\tan \rho$ を摩擦係数とすると $\tan \rho=0.687$

を得る。故に上式は

$$
P=0.218 w(1+0.3435 \Phi)\left(6 h^{2} D \tan \varphi+4 h^{3} \tan ^{2} \Phi\right)
$$

となる。此の式に就いて $D$ 剆ち小円板の直径の 3 通りを, $h$ 郎ち梁さに応じて $P$ なる実験値を满足する如きゅ

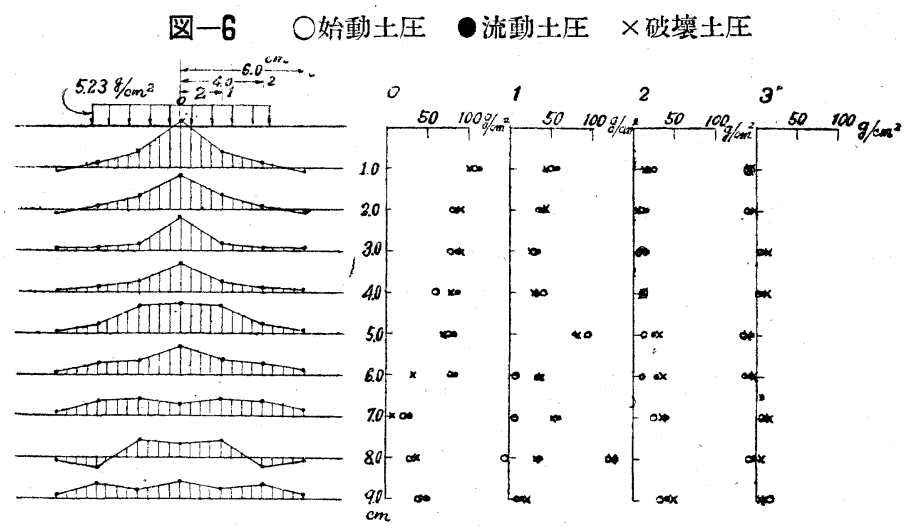
を図式によつて求めた。図一6は この値を示すものである。深さの $3 \mathrm{~cm}$ から $5 \mathrm{~cm}$ 位つ所で点が固李 るのはこの辺で上述の仮定が合ふ からであららか。表面近くに於け る砂の移動状熊は深い点とはかな り違ふために点は一致して来ない のだと思はれる。何れにしても仮 定汇於ける限界角のとり方は砂の 移動の限界が直線的なものとして 要るから，結果は第1次近似的の 値であるが引上抵抗に対する考案 がこれで若し正しければ次第に正確な限界角が得られると思ふ。更に二次元的にこの限界角を調べた。それは硝 子箱の中に砂を入れ，中に入れた小幅の板を引上げ砂硝子面に置いた白墨の粉末の移動を見る方法である。これ

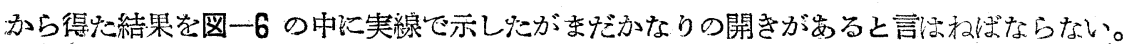

\section{5. 載荷せる場合の圧力}

測定方法はは前と同様であ。荷重としては矢張り砂を用ひた。結果の一例は図一7 の如くである。これは各 点の流動土圧であり，荷重による影響のみを実数値から算出したものである。始動，流動，及び破壊の各応力は 中心からの距離に応じて図 7・6の1,2,3,4の順に示した。図-7に於いて，底面近くに於いて点が不㨢に なるのはこれも Arch action か或な底面からの反力の為ではないかと思ふ。実験回数が少いので未だ允分なる 資料となし得ないので今後も進めて見る積りである。

\section{6. 結 言}

以上簡単な奏験であるが比較的薄い秒層内の垂直圧力に就て得を結果を要約すると，測定器の大いさに恢つて 王力の值が違つて出てくること，これから限界角の値を導き得る可能を持つこと，又，底面近くでは底面の影響 が入つてくると考へられる点である。更に依然として問題なのは砂層の圧力と言ふ時，砂の組織の変形に於いて 如何なる状態を指すかといふことであろう。。

此の実験に要たり工学士神山一君 (当時早大学生) の協力を得さこと, 又日本学術振與会の御援助を受けたこ とを茲に併せ記して感謝の意を表する次第である。 